\section{Original} Article

\begin{tabular}{|l|}
\hline Access this article online \\
\hline Website: \\
www.ajobe.org \\
\hline DOI: \\
10.4103/1817-7417.86035 \\
\hline Quick Response Code: \\
\hline \\
\hline
\end{tabular}

Address for correspondence: Prof. GJ (Deon) Rossouw Ethics Institute of South Africa PO Box 11233, Hatfield 0028 Pretoria South Africa E-mail: deon.rossouw@ethicsa.org

\title{
The Sub-Sahara African survey of Business Ethics as field of teaching, training and research
}

\author{
GJ (Deon) Rossouw \\ Department of Philosophy, University of Pretoria, South Africa. \\ ABSTRACT
}

This article introduces the Global Survey of Business Ethics as field of Teaching, Training and Research. For the purpose of the survey the world was divided into nine regions that cover all countries of the world. This special edition of the African Journal of Business Ethics only focuses on the findings of the Global Survey in one of the nine world regions, viz., Sub-Saharan Africa. This introductory article provides an overview of the Sub-Sahara African region and the four sub-regions in which the 44 countries of SubSaharan Africa were divided for the purpose of this survey. A brief overview of existing literature that reflects on training, teaching and research in the field of Business Ethics in the Sub-Sahara African region is given, after which the research process and methods that were used in the survey are introduced.

Key words: Business Ethics, Teaching, Training, Research, Sub-Saharan Africa

\section{INTRODUCTION}

In 2009 a global survey of Business Ethics as field of Teaching, Training and Research was commissioned by Globethics.net in Geneva. For the purpose of the survey the world was divided into nine regions that cover all countries of the world. These regions are: (1) Latin America, (2) North America, (3) SubSaharan Africa, (4) Europe, (5) Middle East \& North Africa, (6) Central Asia, (7) South \& South-East Asia, (8) East Asia, and (9) Oceania. The objective of this global survey was to determine how Business Ethics as a field of Teaching, Training and Research has developed since 1995 with regard to the following aspects:

- Focus areas in the field of Business Ethics;

- The terms that are used to refer to Business Ethics;

- The topics covered in training programs on Business Ethics;

- The topics covered in formal academic courses on Business Ethics;

- The topics covered in Business Ethics research; and

- The major Business Ethical issues that are foreseen over the next 5 years.

The reason for selecting 1995 as starting date for the survey is because a first attempt to survey the development of Business Ethics on a world-wide scale was conducted in 1995 (and finally published in 1997 (cf. Enderle, 1997)I. The 2009 survey can thus be seen a follow-up on the previous (1995) survey.

In this special edition of the African Journal of Business Ethics the findings of the survey in the Sub-Sahara African region will be reported. In this first article of the special edition an overview will be provided of the Sub-Sahara African region and the four subregions in which the 44 countries of SubSaharan Africa were divided for the purpose of this survey. A brief overview of existing literature that reflects on training, teaching and research in the field of Business Ethics in the Sub-Sahara African region will also be given, after which the research process and methods that were used in the survey will be introduced.

The next four contributions to this special edition will consist of the survey reports of each of the four sub-regions in Sub-Saharan Africa, viz., Western Africa, Southern Africa, Eastern Africa and Central \& Francophone Africa. Finally a concluding article will follow in which a comparative analysis across the four sub-regions of Sub-Saharan Africa will be presented.

\section{THE SUB-SAHARAN AFRICA REGION}

The Sub-Saharan Africa region consists of 44 countries. The official languages in these 
previously colonized countries are predominantly English and French, with the exception of Angola, Mozambique and Guinea Bissau where Portuguese is the official language, and Equatorial Guinea where the official language is Spanish. In some countries in the proximity of North Africa, like Chad, Djibouti, Eritrea, Somalia and Sudan, Arab is also an official language. For the purpose of this survey, the 44 countries in Sub-Saharan Africa were divided into four regions, viz. Western Africa, Southern Africa, Eastern Africa and Central \& Francophone Africa. The four sub-regions and the countries that they consist of are displayed in the Table1.

\section{EXISTING LITERATURE ON BUSINESS ETHICS AS} FIELD OF TEACHING, TRAINING AND RESEARCH

As part of the world-wide survey of Business Ethics

\begin{tabular}{|c|c|}
\hline Sub-region & Countries \\
\hline Southern Africa & $\begin{array}{l}\text { Angola } \\
\text { Botswana } \\
\text { Lesotho } \\
\text { Malawi } \\
\text { Mauritius } \\
\text { Mozambique } \\
\text { Namibia } \\
\text { South Africa } \\
\text { Swaziland } \\
\text { Zambia } \\
\text { Zimbabwe }\end{array}$ \\
\hline Eastern Africa & $\begin{array}{l}\text { Djibouti } \\
\text { Eritrea } \\
\text { Ethiopia } \\
\text { Kenya } \\
\text { Seychelles } \\
\text { Somalia } \\
\text { Sudan } \\
\text { Tanzania } \\
\text { Uganda }\end{array}$ \\
\hline Western Africa & $\begin{array}{l}\text { Benin } \\
\text { Cameroun } \\
\text { Chad } \\
\text { Equatorial Guinea } \\
\text { Gambia } \\
\text { Ghana } \\
\text { Guinea } \\
\text { Liberia } \\
\text { Mali } \\
\text { Niger } \\
\text { Nigeria } \\
\text { Sierra Leone } \\
\text { Togo }\end{array}$ \\
\hline $\begin{array}{l}\text { Central and Francophone } \\
\text { Africa }\end{array}$ & $\begin{array}{l}\text { Burquina Faso } \\
\text { Burundi } \\
\text { Central African Republic } \\
\text { Congo } \\
\text { Democratic Republic of Congo } \\
\text { Gabon } \\
\text { Ivory Coast } \\
\text { Madagascar } \\
\text { Mauritania } \\
\text { Rwanda } \\
\text { Senegal }\end{array}$ \\
\hline
\end{tabular}

(cf. Enderle, 1997: 1475-1483) that was commissioned by ISBEE (International Society of Business, Economics, and Ethics) in preparation of the First ISBEE World Congress in Tokyo in 1996, two studies on Business Ethics were conducted in Sub-Saharan Africa. The one study focussed on Eastern \& Southern Africa (cf. Milanzi, 1997) and the other focussed exclusively on Business Ethics in South Africa (cf. Rossouw, 1997).

Milanzi sketched the socio-political and economic conditions that lead to an increased awareness of Business Ethical issues by governments, businesses, and NGOs in Eastern \& Southern Africa. With regard to teaching on Business Ethics in Eastern \& Southern Africa he claimed that "special units and centers [were] established in 65 percent of colleges and universities to deal with Business Ethics issues" (Milanzi, 1997:1552). Since Milanzi did not provide any evidence in support of this claim and also later on in the same article admitted that there is no "clearly defined subject devoted to Business Ethics" in the training programmes of colleges and universities, it is hard to take this claim seriously. Also with regard to research in the field of Business Ethics, Milanzi reported that "very limited academic work has been done in the field of Business Ethics" (1997:1552). Although he mentioned that some research had been done in the field of Business Ethics, he provided no detail of the amount of work, nor of the topics covered in research at that time.

In his study of Business Ethics in South Africa, Rossouw (1997) indicated with regard to teaching that Business Ethics is being taught in some Business Schools as well as in some departments of Business Management, Philosophy, Human Resource Management and Industrial Psychology. Regarding research in the field of Business Ethics, Rossouw mentioned that a total of 64 articles and 7 books had been published in the period 1987-1995 on Business Ethics related issues (1997:1543). However, no indication was given of the themes or topics that were covered in the research. Rossouw only mentioned the topics in the field of Business Ethics that academics and business leaders regarded as most important at the time. They were in order of priority: cultivation of a moral business culture, affirmative action, work ethic, information security, and the relationship between business and society (1997:1540-1542).

A first attempt at surveying the development of Business Ethics as field of teaching and research on a continental scale in Africa was done by Barkhuizen in a Masters' thesis that was completed in 1999. In her study Barkhuizen found evidence of Business Ethics being taught in 6 African countries, viz. Egypt, Ghana, Kenya, Nigeria, South Africa and Uganda. The bulk of the teaching originated in South Africa. She also identified a total of 167 publications (books and articles) that were published in the field of Business Ethics that either originated in Africa or that were written about Business Ethics in Africa. Once more the bulk of this research originated in South Africa. Barkhuizen used a matrix that distinguished on the one hand between 
Business Ethics on the micro-, meso- and macro-economic levels and on the other hand between descriptive, prescriptive and meta-ethical approaches to Business Ethics. In her categorization of teaching and research in the field of Business Ethics, she found that in both these areas the focus were predominantly on Business Ethics on the micro- and meso-economic levels and that both teaching and research were done mostly from a descriptive and prescriptive approach. In a reflection on the study, Barkhuizen \& Rossouw (2000) concluded that Business Ethics on the macro-economic level as well as meta-ethical approaches to Business Ethics were neglected in Africa.

\section{RESEARCH PROCESS AND METHODOLOGY}

The objective of the survey was to determine how Business Ethics as a field of Teaching, Training and Research has developed since 1995 in Sub-Saharan Africa with regard to the following aspects:

- Focus areas in the field of Business Ethics;

- The terms that are used to refer to Business Ethics;

- The topics covered in training programs on Business Ethics;

- The topics covered in formal academic courses on Business Ethics;

- The topics covered in Business Ethics research; and

- The major Business Ethical issues that are foreseen over the next 5 years.

For the purpose of this study a broad definition of Business Ethics as field of Teaching, Training and Research had been agreed upon, which included economic ethics and sustainability (macro-level), corporate responsibility and corporate citizenship (meso-level) and intra-organisational Business Ethics (micro-level). This definition of the field coincides broadly with the definition used for the 1995 world-wide survey of Business Ethics. Enderle (1997: 1476) explained with regard to the latter survey that: "Business Ethics is understood in a comprehensive sense that includes issues at the individual, organizational, and systemic levels of decision making in business and economic life."

To conduct the research in Sub-Saharan Africa a research team was compiled consisting of a sub-regional coordinator for each of the four sub-regions. The core research team consisted of the following members:

- Sub-Sahara African regional coordinator: Prof. GJ (Deon) Rossouw;

- Western African sub-regional coordinator: Prof. Obiora Ike (Nigeria);

- Southern African sub-regional coordinator: Prof. Marilize Smurthwaite (South Africa);

- Eastern African sub-regional coordinator: Dr. Michael Mawa (Uganda) and

- Central and Francophone African sub-regional coordinator: Prof. Liboire Kagabo (Burundi).
Each of the sub-regional coordinators had the liberty to compile a sub-regional research team as they deemed fit.

The research process was divided into 5 stages, which are outlined below:

- Stage 1- Identifying individual and institutional expertise in Business Ethics: The first task was to identify the individuals and institutions with expertise in the field of Business Ethics in each of the four sub-regions. For the purpose of the survey individual expertise was defined as: Persons in the academic environment (1) who spend a substantial amount ( $25 \%$ or more) of their time on Business Ethics training or teaching, or (2) who have published research in Business Ethics. Institutional expertise in Business Ethics was defined as: Academic, professional and nonprofit (but not commercial) associations/institutions with an explicit focus on teaching, training or research in Business Ethics.

- Stage 2- Data collection: Once individuals and institutions with expertise in the field of Business Ethics had been identified they were requested to provide information on their expertise with regard to Business Ethics as field of Teaching, Training and Research. For this purpose separate survey questionnaires for individuals and institutions were developed.

In addition to the survey questionnaires the following other methods were used to collect data on individual and institutional expertise in the field of Business Ethics in the respective sub-regions:

- Literature reviews;

- Personal interviews;

- Desktop searches; and

- Database analyses.

- Stage 3-Data collation and processing: Once sufficient data had been collected the process of data analysis commenced. Data analysis was done on the data obtained via the survey questionnaires and also via the other methods mentioned above. Through the data analysis categories were identified with regard to:

- Focus areas in the field of Business Ethics;

- The terms that are used to refer to Business Ethics;

- The prevalence and distribution of Business Ethics;

- The topics covered in training programs on Business Ethics;

- The topics covered in formal academic courses on Business Ethics;

- The topics covered in Business Ethics research; and

- The major Business Ethical issues that are foreseen over the next five years.

- Stage 4- Sub-regional reports: The first stage of reporting consisted of the production of sub-regional reports. The sub-regional coordinators were responsible for writing a report in which they reported on the findings in their respective sub-regions and also for 
interpreting (making sense) of the reported findings. The broad structure that was followed in each of the sub-regional reports was:

- Existing literature on Business Ethics as field of Training, Teaching and Research in the sub-region;

- Sub-region-specific methodological considerations; and

- Findings regarding the themes of the survey as listed above.

- Stage 5-Regional Report: The research process culminated in the production of the Regional Report for Sub-Saharan Africa. The regional coordinator was responsible for integrating the four sub-regional reports into a comprehensive regional report for Sub-Saharan Africa. The regional report followed the same broad structured as outlined in stage four above.

In order to collect the required information about the field of Business Ethics a number of research methods were used. These include survey questionnaires, literature reviews, personal interviews, desktop searches, and database analyses. Each of these methods is briefly described and discussed below:

- Method 1-Survey questionnaires: Survey questionnaires were designed for both individuals and institutions with expertise in the field of Business Ethics. After individuals and institutions had been identified who qualified in terms of the respective definitions for individual and institutional expertise in Business Ethics (see definitions outlined in stage 1 above), they were invited to complete the survey questionnaires in one of the following formats:

- Online on the globethics.net website at: http:// www.globethics.net/web/guest/research;

- As a Word document (sent as an e-mail attachment); or

- In hard copy.

All the data were collected on a central database and were made available on a regular basis to the subregional coordinators.

The response to the survey questionnaires was disappointing across all four sub-regions. A total of 48 individual and 23 institutional questionnaires were completed. There are a number of factors that probably contributed to the low response rate to the questionnaires. Foremost amongst these factors are access to electronic communication and both the cost and reliability of internet connectivity in the vast majority of African countries (with South Africa as a notable exception). With the exception of South Africa where most of the questionnaires were completed on-line, questionnaires received from the rest of the Sub-Saharan Africa region were mostly completed in either Word format and then submitted as an e-mail attachment or they were submitted in hard copy. Another factor that probably also contributed to the low response rate, was the fact that the questionnaires were only available in English. In the Central and Francophone Africa region this problem was ameliorated by the sub-regional coordinator who translated both the individual and institutional questionnaires into French. Also in East Africa the fact that the questionnaires were only available in English possibly played a role in the countries in the proximity of North Africa where Arab is widely spoken and also enjoys official language status (such as Chad, Djibouti, Eritrea, Somalia and Sudan). A last factor that also might have contributed to the low response rate to the questionnaires is that the online format of the question was found complicated by some respondents. It also timed out if no data was entered for a 30 minute period, which meant that all data entered before the 30 minute break were lost.

As it became clear fairly early in the research process that the response rate to the questionnaires is likely to be low, greater emphasis was placed on the other research methods, and particularly on personal contacts and interviews (face-to-face, telephonically and electronically) with experts in the field of Business Ethics.

- Method 2- Literature review: A literature review was done to determine whether any previous studies have been done on Business Ethics as field of either training, or teaching, or research. The focus of these literature surveys was to identify previous attempts to reflect on a meta-level on how teaching, training or research on Business Ethics is approached or institutionalized in a specific country or region.

The literature reviewed produced one Africa wide study that was done in 2000 and two regional studies (both published in 1997) that focused on Southern and Eastern Africa.

- Method 3- Personal interviews: Personal interviews were conducted with individuals and representatives of institutions with expertise in the field of Business Ethics. These interviews were conducted either faceto-face, electronically via e-mail or by telephone. The interviews were semi-structured and probed respondents with regard to the same questions that were included in the survey questionnaires.

The personal contacts and interviews with experts in the field turned out to be a valuable source that rendered rich information. It also often had a knockon effect that lead to interviews with further experts mentioned by some of the interviewees, or to experts being willing to complete the questionnaires once they had been prompted to do so in the interview situation.

- Method 4- Desktop search: Since a substantial amount of information related to the main themes of this study are available on publicly accessible websites, desktop searches were done on relevant websites of institutions (such as universities and non-profit organizations) to gather information regarding training, teaching and research in Business Ethics offered by individuals and institutions. 
The desktop search turned out to be a valuable method of data collection in a number of countries since it was the only source of available information. However, the desktop searches were hampered by two problems. The first was the high cost, unavailability or unreliability of internet access. The second was the fact that many institutional websites were poorly developed with scant information and often without a search function to find information related to Business Ethics.

- Method 5- Database analysis: Where databases that captured information about training, teaching or research in the field of Business Ethics were available, such databases were analysed to extract the required information.

Database analyses were particularly helpful in gathering data about publications in the field of Business Ethics. A problem was encountered to link publications to the country of origin of their authors. A solution was eventually found in the form of some databases that do indicate the institutional affiliation of authors. These institutions were then manually matched with specific countries in order to compile a regional database of publications for the Sub-Saharan Africa region. Databases that were particularly valuable were the Africa-Wide: NiPAD, ISI, Scopus, and World of Learning databases.
The information gathered through the above mentioned research methods was first collated and analysed on the sub-regional level and thereafter integrated into the regional report. In what follows, the findings of the survey for each of the four sub-regions in Sub-Saharan Africa will be introduced separately and finally compared in the concluding article.

\section{REFERENCES}

Barkhuysen, B. 1999. A survey of the current status of Business Ethics as an academic field in Africa. Unpublished MA dissertation, Johannesburg: Rand Afrikaans University.

Barkhuysen, B. \& Rossouw, GJ. 2000. Business Ethics as academic field in Africa: its current status. Business Ethics: A European Review, 9(4): 229-235.

Enderle, G. 1997. A worldwide survey of Business Ethics in the 1990s. Journal of Business Ethics, 16(14): 1475-1483.

Milanzi, M.C. 1997. Business Ethics in Eastern and Southern Africa. Journal of Business Ethics, 16(14): 1549-1553.

Rossouw, G.J. 1997. Business Ethics in South Africa. Journal of Business Ethics, 16(14): 1539-1547.

How to cite this article: (Deon) Rossouw GJ. The Sub-Sahara African survey of Business Ethics as field of teaching, training and research. Afr J Bus Ethics 2011;5:61-5.

Source of Support: Nil, Conflict of Interest: None declared

\section{AUTHOR}

Prof. Deon Rossouw is CEO of the Ethics Institute of South Africa and Extraordinary Professor in Philosophy at the University of Pretoria. He was the Founding President of the Business Ethics Network of Africa (BEN-Africa) and a former President of the International Society for Business Economics and Ethics (ISBEE). He is a member of the Sustainability Committee of the Third King Report on Corporate Governance for South Africa. He was responsible for initiating and coordinating the Global Survey of Business Ethics as field of Teaching, Training and Research while he served as Programme Director for Business Ethics at Globethics.net in Geneva during 2008/9.

\section{“QUICK RESPONSE CODE” LINK FOR FULL TEXT ARTICLES}

The journal issue has a unique new feature for reaching to the journal's website without typing a single letter. Each article on its first page has a "Quick Response Code". Using any mobile or other hand-held device with camera and GPRS/other internet source, one can reach to the full text of that particular article on the journal's website. Start a QR-code reading software (see list of free applications from http://tinyurl.com/yzlh2tc) and point the camera to the QR-code printed in the journal. It will automatically take you to the HTML full text of that article. One can also use a desktop or laptop with web camera for similar functionality. See http://tinyurl.com/2bw7fn3 or http://tinyurl.com/3ysr3me for the free applications. 
Reproduced with permission of the copyright owner. Further reproduction prohibited without permission. 